\title{
5.3 Ancient African Christians and Ethnic Identity
}

In the early period of Christian history in ancient North Africa, it is unlikely that Christians understood themselves in terms of a new ethnic identity. ${ }^{56}$ Nevertheless, using anthropological theories of ethnic identity to study early Christians, historical theologians can better appreciate the dynamics at play in extant Christian writings. As Johnson contends, "Awareness of one's theoretical assumptions allows modern readers to better grasp and articulate the contours of ethnicity in the ancient Mediterranean world." $" 57$ The previous chapter discussed the relationship between the language, customs, and other boundary markers of ethnicity from both Roman and African perspectives. This understanding will now inform the reading of the Christian data from ancient North Africa.

The reports of the earliest martyrs offer clues as to the ethnic identity of ancient African Christians. In relation to patria, Rives states, "The names of the martyrs [Scillitan], unlike that of their hometown, were recorded: Speratus, Nartzalus, Cittinus, Donata, Secunda, and Vestia. It is worth noting that several of these were typical African names: these people were not immigrants, but natives of the province who had converted to this new religion." 58 Similarly, Braun deduces from the Scillitans' names that they were "d'origine punique." 59

While similar assumptions could be based on the names of the martyrs associated with Perpetua, their account provides a specific indication in the narration of Felicity's delivery of her child. The narrator reports, "Felicitas, glad that she had safely given birth so that now she could fight the beasts, going from one blood bath to another, from the midwife to the gladiator, ready to wash after childbirth in a second baptism." ${ }^{, 60}$ Blake Leyerle sees in this account strong

56 See, however, Rowan Williams, "Does it Make Sense to Speak of pre-Nicene Orthodoxy?" in The Making of Orthodoxy: Essays in Honour of Henry Chadwick, ed. Rowan Williams, (CUP, 1989), 10, who speaks of early Christian Orthodoxy as "the creation of a new genos"; and discussions in Lieu, "The Race of the God-Fearers," $J T S$ n.s. 46 (1995): 483-501; Lieu, Christian Identity, chapter 8, "The Christian Race"; Denise Kimber Buell, "Rethinking the Relevance of Race for Early Christian Self-Definition," HTR 94 (4 2001): 461-62; and Buell, "Race and Universalism in Early Christianity," JECS 10 (2002): 429-68; and Why This New Race, (New York: Columbia University Press, 2005). Also, see the accusation answered by Tertullian, Ad nat. 1.8; 20.4; Apol. 8 ; Scorp. 10.10 , where Christians are a tertium genus.

57 "Identity," 29.

58 Religion, 223-4; likewise, Rankin, Tertullan, 11, affirms that the Scillitans come "from among the indigenous rural population"; cf. Tertullian Ad. Scap. 3.4.

59 "Aux Orignes," 190. cf. Brown, The Lord's Prayer, 195, asserts that the North African Christian community "was thoroughly Romanized by the time of the incident of the Scillitan martyrs." Brown apparently basis this conclusion on the Scillitan's use of Latin.

60 PSPF 18.3: item Felicitas, saluam se peperisse gaudens ut ad bestias pugnaret, a sanguine ad sanguinem, ab obstetrice ad retiarium, lotura post partum baptismo secundo. 
vestiges of a fertility symbolism - which he associates with Jewish rather than Punic tradition. ${ }^{61}$

Another clue about the ethnic identity of the martyrs and Christians of this period is found in the office of elder in the North African churches. The vision of Saturninus reports that as the martyrs proceed through the heavenly city they see "before the gates Optatus the bishop on the right, and Aspasius the presbyter and teacher...."62 This is one of the first extant references in African Christian history to a unique office of the elder. ${ }^{63}$ Outside of Africa, the presbuteroi of the first century church became the priesthood - distinct from the African seniores laici. ${ }^{64}$ Frend deduced that the phenomenon is attributable to Jewish origins of Christianity in North Africa. ${ }^{65}$ Shaw posits an alternative view of the "peculiarity" of elders in North African Christian churches. ${ }^{66}$

Elders had served as fundamental political institutions in the numerous societies of African towns and villages in the pre-Christian period. Shaw argues, "...the literary sources reveal that elders (also called seniores) who functioned as an integral part of the structure of the Christian Church are to be found in North Africa alone. The coincidence is surely not fortuitous, though the argument for the continuity of the two institutions have been overlooked, deliberately ignored, contested or simply denied." ${ }^{67}$ Shaw believes the indigenous Africans of LibyoPunic descent transferred the role of the local elder into the new Christian communities: "the Christianization of the African countryside signaled a religious revolution of considerable significance to individual attitudes, but not necessarily a radical change in social institutions." allows a distinction between the local governing body of seniores and those of the ecclesial title. He insists, however, that this is due to "an imposed Roman

61 "Blood is Seed," 36; while Leyerle connects Judaic and Phoenician fertility language elsewhere in his article, he attributes this passage and others like it in PSPF (e.g. 21.2) and in Tertullian (Apol. 50.13) to connections with Judaism rather than to a Punic heritage. cf. Wright, "Tertullian," 1029, on "Punic religion" and "the daring blood imagery" of PSPF.

62 PSPF 13.1: "...ante fores Optatum episcopum ad dexteram et Aspasium presbyterum doctorem..." and the imagery in 12.

63 Also, Tertullian, Apol. 39.3ff. Evans, "The Seniores Laici and the Origins of the Church in North Africa," JTS n.s. 12 (1961), 280, states the role, as known during the Donatist controversy, "derived from a much earlier period."

64 Frend, "The Early," 30.

65 Barnes, Tertullian, 274-5, outright rejects Frend's claim, especially in relation to Tert., Apol. 39.3ff., because he does not think lay elders could have presided over meetings and concludes that Tertullian's seniores refers to priests. Shaw, "The Elders of Christian Africa," in Mélanges offerts à R.P. Etienne Gareau, Numéro spéciale de cahiers des études anciennes, (Ottowa, Editions de l'Université d'Ottowa, 1982), 209, reprinted in Shaw, Rulers, Nomads, and Christians in Roman North Africa, (Aldershot: Variorum, 1995), challenges Barnes' conclusion because Tertullian does not allude to them performing any sacerdotal functions.

66 "The Elders," 207-226.

67 Ibid, 207, see note 2 for a survey of the examples.

68 Ibid. 
government." lifetime and into the era of the Donatist controversy. The unique usage of the seniores in North African Christian churches suggests a movement consisting largely of indigenous Africans who naturally retained their ancestral customs and practices. $^{70}$ Such an understanding in no way portrays ethnic conflict as a factor in the persecutions of Christians or the conflict between Christian sects. ${ }^{71}$ Ethnicity is a factor, however, in forming identity, and the identity of the African early Christians, while radically transformed by their new faith, retained a selfunderstanding of their heritage, their uniqueness and their non-Romanness, in other words, their African identities.

\subsection{Tertullian and Ethnic Identity}

The indigenous Africans under Rome belonged to an ethnic category distinct from the Roman colonizers. The colonization of North Africa began a phenomenon of conflict between these two categories of peoples resulting in, among other responses, a solidified understanding of the non-Roman-ness of some of the indigenous population. As the Christian communities in North Africa incorporated a growing majority of indigenous Africans into its membership, ethnic factors began to influence the practices and self-identities of said congregations. Tertullian's constructions of ethnic boundaries such as customs and appearance will now be discussed in order to explore his distinctions between certain people groups. ${ }^{72}$ The following section assumes the tension in his

69 Ibid, 223.

70 For later African Christianity as largely indigenous, see Raven, Rome, 167; Markus, "Christianity," 21-36; Shaw, "African Christianity," who replaces "Donatist" with "African"; and Tilley, The Bible, 18, for the "remnants of Punic culture." A.H.M. Jones, "Were Ancient Heresies National or Social Movements in Disguise?" JTS 10 (1959): 280-98, argues that heresies were not nationalistic, but "regional." Jones' definition of "national," however, is rarely (if ever) proposed; instead, scholars such as Raven are cautious about labeling any form of Christianity as "nationalistic" or coterminous with an ethnic identity, but continue to recognize the trends of some sects in attracting certain people groups. Moreover, as Buell, "Race and Universalism," 468, maintains, "Paying attention to ethnic reasoning helps us reconstruct the diversity among early Christian thinking and practices without recourse to problematic frameworks like orthodoxy, heterodoxy, and heresy." For responses to Jones, see Frend, "Heresy," 39; Markus, "Christianity and Dissent," 25-6; and Ramsay MacMullen, "Tertullian and "National God," JTS n.s. 26 (1975): 405-10.

71 See, however, Christopher D. Stanley, “Neither Jew nor Greek': Ethnic Conflict in GraecoRoman Society," Journal for the Study of the New Testament 64 (D 1996): 101-124, for this phenomenon throughout the Roman Empire and its import for Paul's writings.

72 The lack of data regarding Tertullian's native language requires the subject to be omitted from the present discussion. See, however, H. Hoppe (1932), cited by Altaner, Patrology, (1960), 166, who states, "Tertullian formed 509 new nouns, 284 new adjectives, 28 new adverbs and 161 new verbs..." Although the notion of an "African dialect" of Latin has found little support in contemporary scholarship - see generally, Hilton, "Introduction by John Hilton to Florida in 